\title{
Detection of Cyprinid herpesvirus-3 (CyHV-3) DNA in infected fish tissues by nested polymerase chain reaction
}

\author{
Mansour El-Matbouli ${ }^{1, *}$, Ute Rucker $^{1}$, Hatem Soliman $^{1,2}$ \\ ${ }^{1}$ Institute of Zoology, Fish Biology and Fish Diseases, Faculty of Veterinary Medicine, University of Munich, \\ Kaulbachstr. 37, 80539 Munich, Germany \\ ${ }^{2}$ Veterinary Serum and Vaccine Research Institute, El-Sekka El-Beda St., PO Box 131, Abbasia, Cairo, Egypt
}

\begin{abstract}
Diagnostic tests with high analytical sensitivity are required to detect Cyprinid herpesvirus-3 (CyHV-3) in carriers that have been implicated in the dissemination of this important disease of koi and common carp Cyprinus carpio. A nested polymerase chain reaction (PCR) test was developed to detect CyHV-3 DNA in tissues of infected fish. The 2-round PCR amplified 529 and $379 \mathrm{bp}$ segments of the CyHV-3 gene coding for the major capsid protein using specific external and internal primers, respectively. The PCR test did not amplify genomic DNA from either Cyprinid herpesvirus-1 (CyHV-1) or Cyprinid herpesvirus-2 (CyHV-2). The nested PCR test detected CyHV-3 DNA at a 10-fold lower concentration than a routinely used, 1-round test. Hence, the new method should provide more sensitive diagnosis of CyHV-3 infection among koi and carp populations.
\end{abstract}

KEY WORDS: Diagnosis · Cyprinid herpesvirus-3 - CyHV-3 - Nested polymerase chain reaction Koi $\cdot$ Common carp

Resale or republication not permitted without written consent of the publisher

\section{INTRODUCTION}

Herpes viruses are DNA viruses that can cause diseases in fish, with symptoms ranging from skin growths of benign appearance to severe systemic disorders (Hedrick \& Sano 1989). One of these herpes viruses is the koi herpesvirus (KHV). Although the virus is currently classified as a DNA-virus belonging to the virus family Herpesviridae (Hedrick et al. 2000), one report disputed the accuracy of this classification and named the virus as carp nephritis and gill necrosis virus, CNGV (Ronen et al. 2003). Recent works based on morphology and genetics present strong evidence that the agent is indeed a herpesvirus (Waltzek et al. 2004), and finally it was designated Cyprinid herpesvirus-3 (CyHV-3; Waltzek et al. 2005).

CyHV-3 can be differentiated from another fish herpes virus Cyprinid herpesvirus-1 (CyHV-1) that causes carp pox by cell line specificity, the type of cytopathic effect (CPE) and antigenic properties. CyHV-3 also causes disease in older fish, while contributing to outbreaks among all ages of koi and common carp (Hedrick et al. 2000).

CyHV-3 is a highly contagious viral disease which threatens the ornamental koi carp industry as well as the common carp, which is the world's fourth mostfarmed fish (Ronen et al. 2003). CyHV-3 disease outbreaks were first reported in Germany in 1997 (Bretzinger et al. 1999) and from the USA and Israel in 1998 (Hedrick et al. 2000, Ronen et al. 2003). Outbreaks continued in in these countries while new cases appeared throughout Europe (UK, France, Italy, Netherlands, Belgium, Denmark, Switzerland, Austria, and Luxembourg) (Body et al. 2000, Haenen \& Engelsma 2004, Way et al. 2004) as well as China, Taiwan, Indonesia, South Africa and Japan (Miyazaki et al. 2000, Haenen \& Engelsma 2004, Sano 2004, Tu et al. 2004).

Rapid spread of CyHV-3 is connected predominantly with the movement of fish, with consequent spreading 
of disease (Hedrick 1996). There are 3 main mechanisms through which CyHV-3 has spread rapidly worldwide: intensive fish culture, koi exhibitions and regional, domestic and international trading (Gilad et al. 2003). The importance of CyHV-3 disease results from the considerable economic losses to the koi and carp industries that impact fish breeders, retailers and hobbyists through cumulative mortalities (Gilad et al. 2003, Ronen et al. 2003).

The most consistent sign of the disease is discoloration, increased respiratory frequency (Gray et al. 2002), pale, swollen, patchy gills and skin lesions (Oh et al. 2001). Histological examination reveals mass proliferations of gill epithelium (with necrotic and degenerative changes) and intranuclear inclusions in the infected cells.

Standard diagnostic methods have been based on isolation of the virus in cell cultures using koi fin (KF-1) cell lines to demonstrate CPEs (Hedrick et al. 2000). Although this method is effective at detecting the virus during the mortality phase of the disease, it is timeconsuming and not suitable for detecting asymptomatic fish carrying the virus - those responsible for spreading the disease (Gilad et al. 2002).

A significant advance in laboratory diagnosis of infectious diseases occurred with improvement of molecular biological methods employing the polymerase chain reaction (PCR). PCR offers an accurate, rapid and sensitive demonstration of disease agents by amplification of their nucleic acids (Koutná et al. 2003). Several different PCR tests are in use (e.g. Gilad et al. 2002, Gray et al. 2002) to detect CyHV-3 in koi and common carp. A real-time TaqMan PCR assay was developed for detection and quantification of CyHV-3 DNA (Gilad et al. 2004). Loop-mediated isothermal amplification (LAMP) has been developed recently to amplify and detect CyHV-3 DNA with high specificity, sensitivity and rapidity under isothermal conditions (Gunimaladevi et al. 2004, Soliman \& El-Matbouli 2005).

We routinely use PCR assays for detection of CyHV-3. From 2001 to 2005, we ran about 1323 PCR tests for routine disease diagnostics and for inspection of imported koi (Table 1). In some cases, we were not satisfied with negative PCR results as both the case history and histological examination indicated CyHV-3 infection. Given the wider demand of European Union (EU) for a sensitive test to detect CyHV-3 carriers, and to stop the spread of infection among the EU country members, we developed a nested PCR assay for detection of CyHV-3 at very low concentrations. This new test serves as an additional diagnostic step for detection of CyHV-3 carriers and latent infections and should reduce the spread and number of outbreaks of the disease.
Table 1. Cyprinid herpesvirus-3 (CyHV-3) test results of samples analysed from 2001 to 2005 by the PCR assay developed by Gilad et al. (2002)

\begin{tabular}{|lccc|}
\hline Year & $\begin{array}{c}\text { Total } \\
\text { number }\end{array}$ & $\begin{array}{c}\text { Positive } \\
\text { samples }\end{array}$ & $\begin{array}{c}\text { Negative } \\
\text { samples }\end{array}$ \\
\hline 2001 & 67 & 26 & 41 \\
2002 & 152 & 69 & 83 \\
2003 & 448 & 90 & 358 \\
2004 & 361 & 27 & 334 \\
2005 & 295 & 51 & 244 \\
Total 2001-2005 & 1323 & 263 & 1060 \\
\hline
\end{tabular}

\section{MATERIALS AND METHODS}

DNA extraction from CyHV-3 infected tissues. During the period from 2001 to 2005, suspected CyHV-3 cases were submitted to our laboratory either as live fish or fixed organs in $70 \%$ ethanol. Gills, kidney, spleen and brain were sampled. DNA was extracted from these tissues using the QIAamp ${ }^{\circledR}$ DNA mini kit (QIAGEN) according to the manufacturer's instructions. Genomic DNA of CyHV-3 was extracted from virus culture (KF-1 cell line) supernatants using QIAamp DNA blood kit (QIAGEN) according to the manufacturer's instructions. Genomic DNA of specific pathogen-free (SPF) koi (from the Institute of Zoology, Fish Biology and Fish Diseases, Faculty of Veterinary Medicine, University of Munich, Germany) was extracted using the QIAamp DNA mini kit, tissue protocol, (QIAGEN) according to the manufacturer's instructions. Genomic DNA of CyHV-1 and Cyprinid herpesvirus-2 (CyHV-2) were also extracted from virus culture supernatant at the Fish Health Laboratory, University of California, Davis, CA, USA. Extracted DNA was stored at $-20^{\circ} \mathrm{C}$ for future use.

Primer design. Two primer sets (external and internal) were designed based on the CyHV-3 major capsid protein gene (Waltzek et al. 2005, GenBank Accession number AY939864) for specific detection of CyHV-3 in tissues. Possible homology of the selected oligonucleotides was excluded by checking them with primer detective software (DNAstar program, Institute of Fish Diseases, Faculty of Veterinary Medicine, University of Munich, Germany). The external primer pair (sense: 5'-ACCAACTTTAGCACGGACGAC-3'; antisense: 5'-ACTTGACCAGGTACAGCAGC-3') and the internal primer pair for nested PCR (sense: 5'-CTTTAGCACGGACGACTTTGGC-3'; antisense: 5'-GTAGACGATGGACAGGGAG-3') amplified segments of 529 and 379 bp from the CyHV-3 DNA, respectively.

PCR. Amplification was performed using $50 \mu \mathrm{l}$ total volume, comprising: $45 \mu \mathrm{l}$ of $1.1 \times$ ReddyMix $^{\mathrm{TM}} \mathrm{PCR}$ Master mix (ABgene) [containing: $75 \mathrm{mM}$ Tris- $\mathrm{HCl}, \mathrm{pH}$ 
8.8, $20 \mathrm{mM}\left(\mathrm{NH}_{4}\right)_{2} \mathrm{SO}_{4}, 1.5 \mathrm{mM} \mathrm{MgCl}, 0.01 \%(\mathrm{v} / \mathrm{v})$ Tween ${ }^{\circledR} 20,0.2 \mathrm{mM}$ each of dATP, dCTP, dGTP and dTTP, 1.25 units of Taq DNA polymerase and red dye for electrophoresis], 20 pmol of each external primer, $1 \mu \mathrm{l}$ of DNA template. Using a Mastercycler gradient thermocycler (Eppendorf), the reaction mixture was subjected to 30 amplification cycles, comprising: $94^{\circ} \mathrm{C}$ denaturing for $45 \mathrm{~s}, 59^{\circ} \mathrm{C}$ annealing for $45 \mathrm{~s}$ and $72^{\circ} \mathrm{C}$ extension for $45 \mathrm{~s}$. The amplification cycles were preceded by an initial denaturing step of $94^{\circ} \mathrm{C}$ for $5 \mathrm{~min}$, followed by an extended elongation step of $72^{\circ} \mathrm{C}$ for $7 \mathrm{~min}$. These conditions were found to be optimal for maximum amplification of the desired DNA fragment and minimization of secondary products using a standard optimisation procedure of varying $\mathrm{Mg}^{2+}$ concentrations, annealing and extension temperatures.

Nested PCR. The PCR reaction mixture contained $1 \mu$ of the amplification product of the first PCR, $20 \mathrm{pmol}$ of each internal primer, $45 \mu \mathrm{l}$ of the $1.1 \times$ ReddyMix $^{\mathrm{TM}}$ PCR Master mix (75 mM Tris- $\mathrm{HCl}, \mathrm{pH} 8.8$, $20 \mathrm{mM}\left(\mathrm{NH}_{4}\right)_{2} \mathrm{SO}_{4}, 1.5 \mathrm{mM} \mathrm{MgCl}_{2}, 0.01 \%(\mathrm{v} / \mathrm{v})$ Tween ${ }^{\circledR}$ 20, $0.2 \mathrm{mM}$ each of dATP, dCTP, dGTP and dTTP, 1.25 units of Taq DNA polymerase and red dye for electrophoresis) in a final volume of $50 \mu \mathrm{l}$. Nested PCR comprised 30 cycles of: $45 \mathrm{~s}$ at $94^{\circ} \mathrm{C}, 45 \mathrm{~s}$ at $59^{\circ} \mathrm{C}, 45 \mathrm{~s}$ at $72^{\circ} \mathrm{C}$; the reaction was preceded by $94^{\circ} \mathrm{C}$ for $5 \mathrm{~min}$ and finished by $72^{\circ} \mathrm{C}$ for $7 \mathrm{~min}$.

After optimization of the nested PCR assay, the external and internal primers were tested on a random pool of samples that had produced negative results using the primers of Gilad et al. (2002). A negative control (no initial template DNA) was included with all PCR and nested PCR runs.

Detection of the PCR product. The amplified PCR products were analysed by electrophoresis on $1.5 \%$ agarose gels in Tris acetate-EDTA buffer (TAE, $0.04 \mathrm{M}$ Tris acetate, $1 \mathrm{mM}$ EDTA) stained with ethidium bromide. The DNA molecular weight standard $100 \mathrm{bp}$ DNA ladder (Cambrex Bioscience) was used to comparatively determine the molecular size of the PCR and nested PCR amplicons.

Cloning and sequencing of nested PCR products. For sequencing, DNA fragments were separated from agarose gel, excess primers and unincorporated nucleotides using the MinElute gel extraction kit (QIA$\mathrm{GEN})$, then cloned into the $\mathrm{pCR}^{\circledR} 4-\mathrm{TOPO}^{\circledR}$ vector using TOPO TA cloning ${ }^{\circledR}$ kit for sequencing (Invitrogen) according to the manufacturer's instructions. Recombinant plasmids were purified from Escherichia coli using the FastPlasmid Mini Kit (Eppendorf) following to the manufacturer's instructions. Plasmid concentrations were determined by spectrophotometry. Cloned PCR products were sequenced in a commercial sequencing laboratory (SEQLAB), then compared with the CyHV-3 major capsid protein gene sequence; products were also subjected to a BLAST search for sequence homology in the GenBank database.

Specificity and sensitivity of the nested PCR assay. The specificity of the primer sets constructed for the detection of CyHV-3 in infected tissues was checked using DNA from carp pox herpesvirus (CyHV-1), haematopoietic necrosis herpesvirus of goldfish (CyHV-2). Genomic DNA of SPF koi fish was tested for possible non-specific amplification.

The sensitivity of the nested PCR assay was tested by amplifying 10-fold serial dilutions of CyHV-3 DNA. Results were compared with the 1-round PCR assay of Gilad et al. (2002).

\section{RESULTS}

\section{PCR and nested PCR}

A fragment of the appropriate size (529 bp for PCR and 379 bp for nested PCR) (Fig.1), was amplified from the CyHV-3 DNA. The effective and specific amplification of the target nucleic acid sequence was preceded by optimisation of PCR conditions (using the gradient PCR test to select the optimum annealing temperature for the external and internal

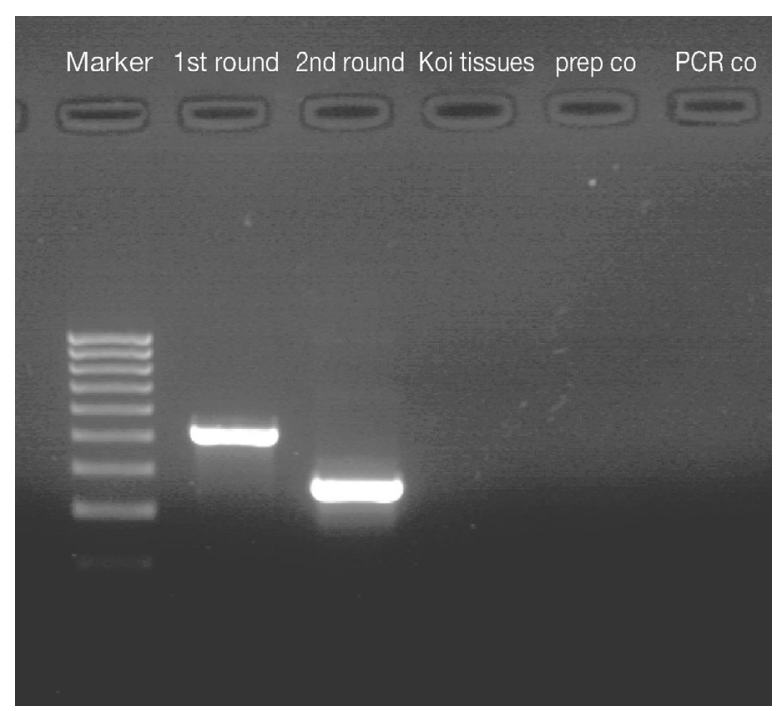

Fig. 1. Agarose gel electrophoresis of the 1- and 2-round Cyprinid herpesvirus-3 (CyHV-3) nested PCR test DNA amplicons utilizing specific external and internal primer sets of the CyHV-3 major capsid protein gene. Separation is on a $1.5 \%$ agarose gel and staining is with ethidium bromide. Marker: 100 bp DNA ladder; 1st round: a 529 bp segment detected in pure CyHV-3 genomic DNA; 2nd round: a 379 bp segment detected in pure CyHV-3 genomic DNA; Koi tissues: no amplicons appeared with the genomic DNA of the specific pathogen-free (SPF) koi tissues; prep co: no amplicons appeared using the DNA extraction preparation control; PCR co: negative (no template) control 
primers). The primers selected did not amplify genomic DNA of SPF koi fish. Both the preparation control (controls for DNA contamination during the DNA extraction process) and the PCR control (PCR reaction mixture without DNA template - controls for contamination during the PCR preparation) were negative (Fig. 1)

\section{Specificity and sensitivity of the nested PCR assay}

As expected, the external and internal primers amplified 529 and 379 bp fragments from CyHV-3 DNA, respectively. No DNA from the CyHV-1 or -2 or genomic DNA of SPF koi fish was amplified (Fig. 2).

The nested PCR assay detected CyHV-3 DNA diluted to $10^{6}$ (Fig. 3), while the routinely used 1-round PCR assay's detection limit was dilution to $10^{5}$ (Fig. 4).

\section{Sequence analysis}

The nucleotide sequence alignments between the 529 and $379 \mathrm{bp}$ fragments and the counterpart of the CyHV-3 major capsid protein gene (Waltzek et al. 2005, Accession number AY939864) revealed 100\% homology. The BLAST search also revealed 100\% homology with the CyHV-3 major capsid protein gene.

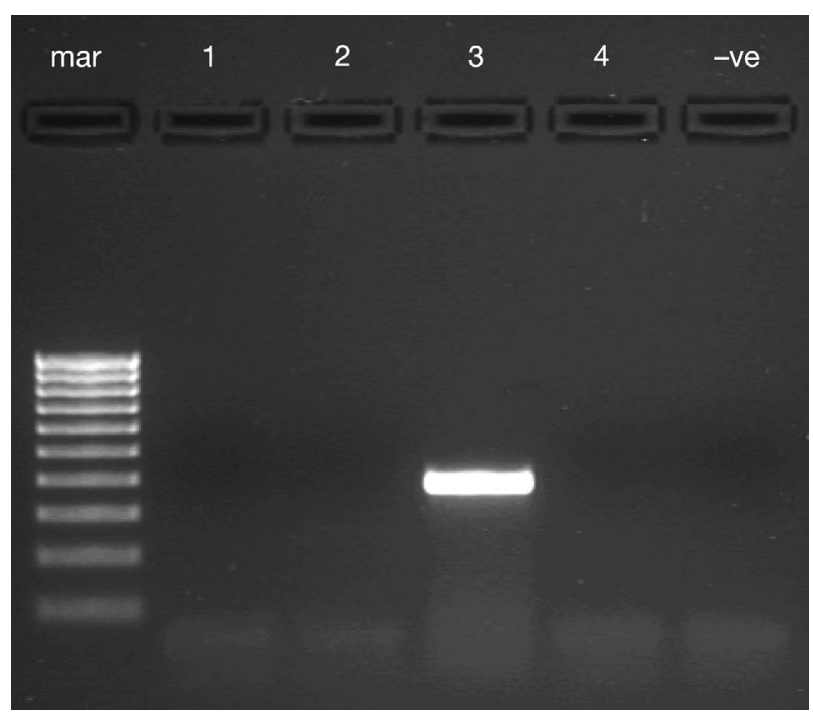

Fig. 2. Agarose gel electrophoresis demonstrating the specificity of the nested PCR primers constructed in amplifying the $379 \mathrm{bp}$ segment of the Cyprinid herpesvirus-3 (CyHV-3) DNA; no amplicons appeared with the other viruses tested or the genomic DNA of specific pathogen-free (SPF) koi tissues. mar: 100 bp DNA ladder; Lane 1: carp pox herpesvirus (Cyprinid herpesvirus-1, CyHV-1); Lane 2: haematopoietic necrosis herpesvirus of goldfish (Cyprinid herpesvirus-2, CyHV-2); Lane 3: CyHV-3 DNA; Lane 4: genomic DNA of the SPF koi tissues; -ve: negative (no template) control

\section{DISCUSSION}

Since the late 1990s, a new disease with mortalities reaching $95 \%$ has been observed in koi and common carp. Outbreaks of the disease have been reported in common carp farms in Germany, and it poses a serious threat to the extensive pond culture of food carp in eastern European countries, as well as to wild carp populations all over Europe (Way 2004). The disease has resulted in significant economic loss worldwide totalling US\$5.5 million in Indonesia alone, approximately $\$ 1.5$ to 2.5 million in Japan and $\$ 3$ million annually in Israel (AFS-FHS 2004, Waltzek \& Hedrick 2004). In addition to losses due to mortalities, the disease has had a negative impact on the international trade of koi, resulting in lowered sales and cancelled exhibition events (Waltzek \& Hedrick 2004).

For these reasons, rapid detection of $\mathrm{CyHV}-3$ is essential for prevention of further outbreaks and for protection of common carp aquaculture, as well as for protection of koi culture as a pleasurable hobby. Diagnosis of CyHV-3 disease has typically been laborious and time-consuming, involving examination for clinical signs and characteristic microscopic lesions and isolation of the virus (Hedrick et al. 2000). Virus culture requires fresh tissue samples and is not suitable for detection of the virus in CyHV-3 survivors, which can act as carriers to spread the disease (Gilad et al. 2002).

PCR molecular techniques offer rapid and sensitive methods for disease diagnosis that can overcome the difficulties of the ordinary diagnostic methods. PCR assays permit detection of separate fragments of viral nucleic acid and obviate the need for intact virus particles for isolation in cell cultures (Koutná et al. 2003). PCR assays facilitate diagnosis by direct visualisation of specific bands on ethidium bromide-stained gels, which is easier and faster than microscopic examination of tissue sections.

A 1-round PCR was developed to diagnose CyHV-3 infection (Gilad et al. 2002, Gray et al. 2002). From 2001 until the present, we have used these protocols for analysing samples sent to our laboratory from veterinarians and fish importers. Very often, fish mortalities continued in koi population even when results of the 1-round PCR assay were negative for CyHV-3. For this reason the sensitivity of the PCR test ought to be increased, especially for virus detection in asymptomatic carrier fish.

We developed a nested PCR assay using external and internal primers specific to the major capsid protein gene of $\mathrm{CyHV}-3$. This specificity diminishes the possibility of false positive results because the internal primers used in the 2-round amplification act as internal control by confirming the presumptive product of the initial amplification (Porter-Jordon et al. 1990). The 


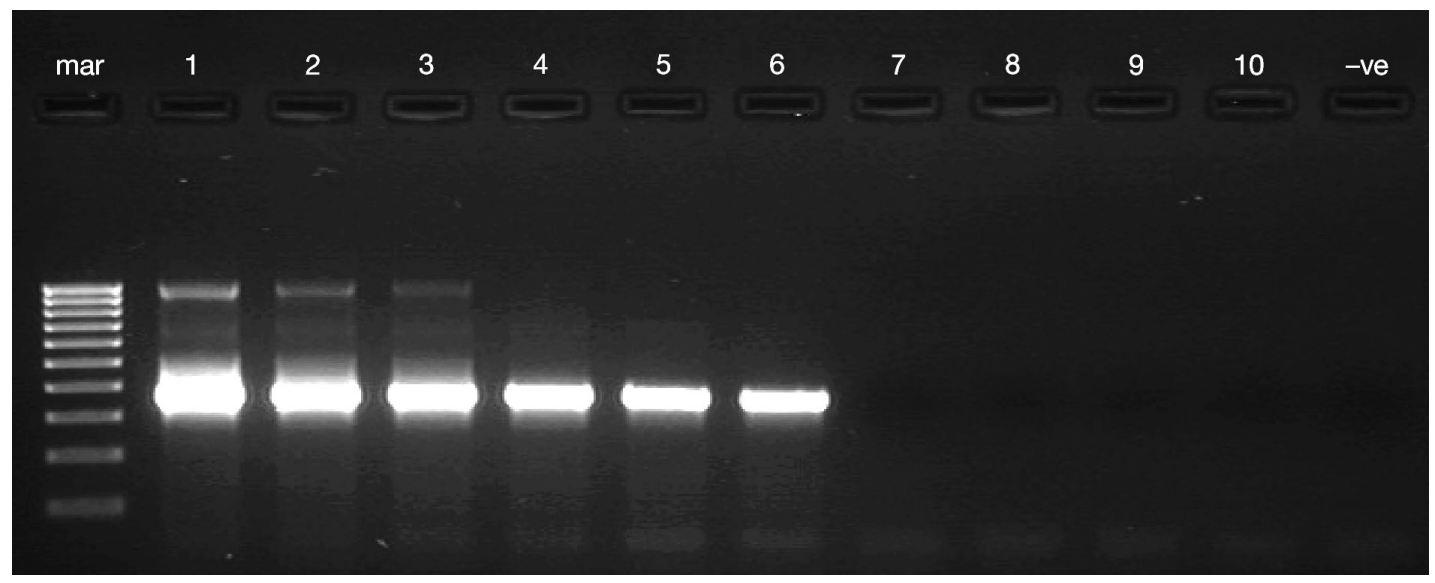

Fig. 3. Agarose gel electrophoresis showing the lower detection limit of the nested PCR assay developed by amplification of a 10fold dilution series of Cyprinid herpesvirus-3 (CyHV-3) DNA. The nested test was able to detect the virus DNA at a dilution of $10^{6}$. mar: $100 \mathrm{bp}$ DNA ladder; Lane 1: dilution of $10^{1}$; Lane 2: dilution of $10^{2}$; Lane 3: dilution of $10^{3}$; Lane 4 : dilution of $10^{4}$; Lane 5: dilution of $10^{5} ;$ Lane 6: dilution of $10^{6} ;$ Lane 7 : dilution of $10^{7} ;$-ve: negative control

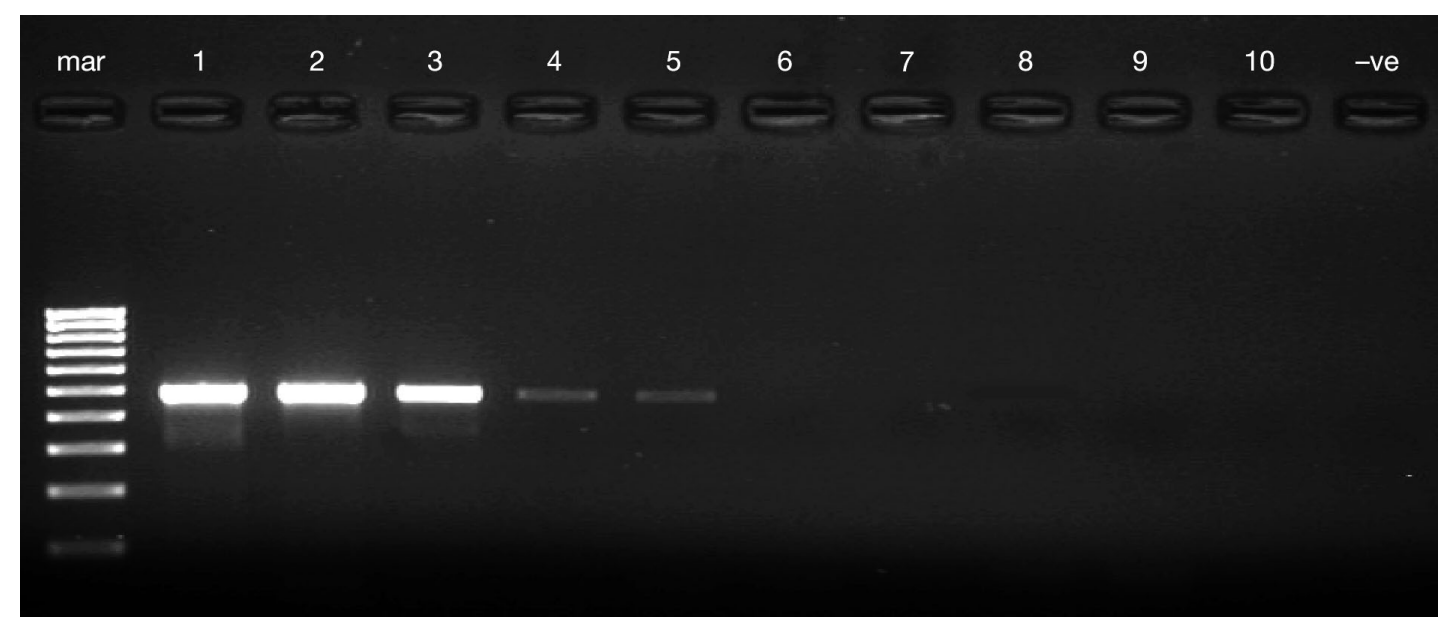

Fig. 4. Agarose gel electrophoresis showing the lower detection limit of Gilad's (2002) PCR assay by amplification of a 10-fold dilution series of Cyprinid herpesvirus-3 (CyHV-3) DNA. The nested test is able to detect the virus at a dilution of $10^{5}$. mar: 100 bp DNA ladder; Lane 1: dilution of $10^{1}$; Lane 2: dilution of $10^{2}$; Lane 3: dilution of $10^{3}$; Lane 4: dilution of $10^{4}$; Lane 5: dilution of $10^{5}$; Lane 6: dilution of $10^{6}$; Lane 7 : dilution of $10^{7} ;$-ve: negative control

nested PCR did not amplify other viruses (CyHV-1 and -2) nor did it amplify DNA of SPF koi tissues, confirming the CyHV-3-specificity of the primers. To ensure that the amplified segments were the exact fragments from the CyHV-3 gene, the PCR and nested PCR products were cloned, sequenced and subjected to alignment; sequence comparison confirmed that the PCR amplified 529 and 379 bp fragments of CyHV-3 DNA. Although the LAMP assays developed by Gunimaladevi et al. (2004) and Soliman \& El-Matbouli (2005) are rapid, simple and inexpensive, they have the same sensitivity as the PCR assay of Gilad et al. (2002) (Soliman \& El-Matbouli 2005). The nested PCR assay developed in this study is 10 times more sensitive than the 1-round PCR assay of Gilad et al. (2002).
PCR methodologies developed by Gilad et al. (2002) and Gray et al. (2002) used primers designed from DNA restriction fragment sequences located in noncoding regions of the viral DNA. These sequences may not be conserved in newly emerging strains of KHV, as a result of which they may be undetectable (Haenen et al. 2004). This may explain the high sensitivity of our nested PCR test, which used primers designed from protein-coding regions (major capsid protein gene) of the KHV genome. As this sequence is protein-coding, it will be conserved in newly emerging strains of KHV. As such, its detection capability will be higher than that of other sequences located in non-coding regions.

We tested the ability of the nested PCR assay developed to detect CyHV-3 DNA in infected tissues. It was 
able to detect the virus DNA in samples that were previously diagnosed as negative using the PCR assay of Gilad et al. (2002). Our new method could be used as a screening test for imported koi or common carp to prevent introduction and spread of CyHV-3.

Further experiments are needed to demonstrate the ability of the test to detect latent CyHV-3 infections by testing asymptomatic experimentally infected fish over long periods after infection.

Acknowledgements. We thank R. Hedrick, University of California, Davis, California, USA, for providing Genomic DNA from CyHV-1 and CyHV-2.

\section{LITERATURE CITED}

AFS-FHS (American Fisheries Society - Fish Health Section) (2004) Standard procedures for aquatic animal health inspections. FHS blue book: suggested procedures for the detection and identification of certain finfish and shellfish pathogens. AFS-FHS, Bethesda, MD

Body A, Lieffring F, Charlier G, Collard A, (2000) Isolation of virus-like particles from koi (Cyprinus carpio) suffering gill necrosis. Bull Eur Assoc Fish Pathol 20:87-88

Bretzinger A, Fischer-Scherl T, Oumouna M, Hoffmann R, Truyen U (1999) Mass mortalities in koi, Cyprinus carpio, associated with gill and skin disease. Bull Eur Assoc Fish Pathol 19:182-185

Gilad O, Yun S, Andree K, Adkison M, Zlotkin A, Bercovier H, Eldar A, Hedrick R (2002) Initial characteristics of koi Herpesvirus and development of a polymerase chain reaction assay to detect the virus in koi, Cyprinus carpio koi. Dis Aquat Org 48:101-108

Gilad O, Yun S, Adkison M, Way K, Willits N, Bercovier H, Hedrick R (2003) Molecular comparison of isolates of an emerging fish pathogen, koi herpesvirus, and the effect of water temperature on mortality of experimentally infected koi. J Gen Virol 84:2661-2668

Gilad O, Yun S, Zagmutt-Vergara FJ, Leutenegger CM, Bercovier H, Hedrick RP (2004) Concentrations of a koi herpesvirus (KHV) in tissues of experimentally infected Cyprinus carpio koi as assessed by real-time TaqMan PCR. Dis Aquat Org 60:179-187

Gray W, Mullis L, Lapatra S, Groff J, Goodwin A (2002) Detection of koi herpesvirus DNA in tissue of infected fish. J Fish Dis 25:171-178

Gunimaladevi I, Kono T, Venugopal MN, Sakai M (2004) Detection of koi herpesvirus in common carp, Cyprinus carpio L., by loop-mediated isothermal amplification. J Fish Dis 27:583-589

Haenen OLM, Engelsma MY (2004) Global distribution of KHV with particular reference to Europe. International Workshop on Koi Herpesvirus. Available at: www.frmltd.com/workshop-KHV.htm

Editorial responsibility: Dieter Steinhagen, Hannover, Germany
Haenen OLM, Way K, Bergmann SM, Ariel E (2004) The emergence of koi herpesvirus and its significance to European aquaculture. Bull Eur Assoc Fish Pathol 24:293-307.

Hedrick RP (1996) Movement of pathogens with the international trade of live fish: problems and solutions. Rev Sci Tech 15:523-531

Hedrick R, Sano T (1989) Herpesviruses of fishes. In: Ahne W, Kurstak E (eds) Viruses of lower vertebrates. SpringerVerlag, Berlin, p 161-170

Hedrick R, Gilad O, Yun S, Spangenberg J and 5 others (2000) A herpesvirus associated with mass mortality of juvenile and adult koi, a strain of common carp. J Aquat Anim Health 12:44-57

Koutná M, Vesely T, Psikal I, Hulová J (2003) Identification of spring viraemia of carp virus (SVCV) by combined RTPCR and nested PCR. Dis Aquat Org 55:229-235

Miyazaki T, Okamoto H, Kageyama T, Kobayashi T (2000) Viremia associated ana-aki-byo, a new viral disease in colour carp Cyprinus carpio in Japan. Dis Aquat Org 39:183-192

Oh M, Jung S, Choi T (2001) A viral disease occurring in cultured carp Cyprinus carpio in Korea. Fish Pathol 36: $147-151$

Porter-Jordon K, Rosenberg EI, Keiser JF (1990) Nested polymerase chain reaction assay for the detection of cytomegalovirus overcomes false-positives caused by contamination with fragmented DNA. J Med Virol 2:85-91

Ronen A, Perelberg A, Abramowitz J, Hutoran M, Tinman S, Bejerano I, Steinitz M, Kotler M (2003) Efficient vaccine against the virus causing a lethal disease in cultured Cyprinus carpio. Vaccine 21:4677-4684

Sano M (2004) Regional updates Japan. International Workshop on Koi Herpesvirus. Available at: www.frmltd.comKHV.htm

Soliman H, El-Matbouli M (2005) An inexpensive and rapid diagnostic method of the koi herpesvirus (KHV) infection by a loop-mediated isothermal amplification method. Virol J 2:83

Tu C, Weng MC, Shiau JR, Lin SY (2004) Detection of koi herpesvirus in koi Cyprinus carpio in Taiwan. Fish Pathol 39: 109-110

Waltzek TB, Hedrick RP (2004) Koi herpesvirus update 2004. California veterinarian, July - August 2004. California Veterinary Medical Association, Davis, CA

Waltzek TB, Kelley GO, Yun SC, McDowell TS, Hedrick RP (2004) Relationships of koi herpesvirus (KHV) to herpeslike viruses of fish and amphibians. Proc 35th Annu Conf Int Assoc Aquat Anim Med 35:16-17

Waltzek TB, Kelley GO, Stone DM, Way K and 6 others (2005) koi herpesvirus respresents a third cyprinid herpesvirus (CyHV-3) in the family Herpesviridae. J Gen Virol 86: 1659-1667

Way K (2004) Koi herpesvirus - a threat to wild carp. Trout News 38:32-35

Way K, LeDeuff RM, Stone DM, Denham KL, St-Hilaire S (2004) Koi herpesvirus diagnostic and research at CEFAS Weymouth laboratory 2000-2003. International Workshop on Koi Herpesvirus. Available at: www.frmltd.com/workshop-KHV.htm

Submitted: September 21, 2006; Accepted: July 26, 2007

Proofs received from author(s): October 15, 2007 